\title{
THE MIGRATION OF QUALIFIED LEBANESE WOMEN TO FRANCE
}

\section{Suzanne Menhem}

(Associate Professor at The Lebanese University Institute of Social Sciences Section-II, RabiehLebanon and Researcher affiliate with the Lebanese Emigration Research Center of Notre Dame University, Lebanon

E-mail address: suzanne.menhem@gmail.com

Keywords: Female migration, highly skilled migration, migration trajectories, profeesion, autonomy, Lebanon, France.

\begin{abstract}
Lebanon is defined as a country of emigration and immigration. Whereas previously, emigration was considered a male migration. Gradually, in recent years emigration has evolved and is becoming feminine also. Independent female migration is a growing phenomenon in the Lebanese society although men still play an important role in the migration project.

In the past, women were emigrating most often in the context of family reunification, accompanying their husbands to join a member of their families. The majority of migrant women today are leaving the country for so many reasons (further education, work, etc.) and not only to join their husbands. This article examines highly skilled female migration from Lebanon.

In France, the migration of skilled workers from Lebanon has experienced very rapid growth in the last decade. However, female migration does not seem to have been the subject of a sociological reading. The study includes qualitative analysis of twenty five cases studied of Lebanese skilled migrant women in France, especially a university degree or equivalent (nurses, architects, teachers, doctors, engineers, lawyers, researchers ...) who were not married or go join their family when they have emigrated, and they have a good command of French language, and who were not dual nationality holders.

This article aims to fill some gaps in this area, examining the reasons for change: migration path, the link with the country of origin, the impact of female migration on their personal, social, cultural and family, their return project, exchanges on the remittances levels, career transition path and entrepreneurship, adaptations, their social networks, their identity reconstruction, etc. Besides, there are also non-measurable aspects noted as the autonomy of women to discuss.
\end{abstract}

\section{INTRODUCTION}

Lebanon is defined as a country of emigration and immigration. Whereas previously, emigration was considered a male migration. Gradually, in recent years emigration has evolved and is becoming feminine also. Independent female migration is a growing phenomenon in the Lebanese society although men still play an important role in the migration project.

In the past, women were emigrating most often in the context of family reunification, accompanying their husbands or joining a member of their families. The majority of migrant women today are leaving the country for so many reasons (further education, work, etc.) and not only to join their husbands. This article examines highly skilled female migration from Lebanon.

This article aims to fill some gaps in this area, examining the reasons for change: migration path, the link with the country of origin, the impact of female migration on their personal, social, cultural and family, their return project, exchanges on the remittances levels, career transition path and entrepreneurship, adaptations, their social networks, their identity reconstruction, etc. Besides, there are also non-measurable aspects noted as the autonomy of women to discuss.

\section{MIGRATION IN FRANCE}

France has long been a special area of migration, the first migrants in the nineteen century ftom neighboring countries such as Belgium, England, Germany and Switzerland. In the twentieth 
century, after the First World war, the migrants come to France from Poland Italy, Spain. After the Second World War, most of the migrants come from Portugal Maghreb, and more recently from sub-Saharan Africa and Asia. For Pison, net migration is in proportion to the population in the years 1950 and 1960 and higher in France than in the US. He added that since 1970, it is the reverse, the input is being reduced in France has instead increased in the United States. Apart from these economic differences the two countries have a long history of immigration. The immigrant population was gradually built up. Migrants have opportunities, come to search for job to study, or to join a family member ... They were many and stayed in the host country. When migrants remained in the host country, others have decided to change destinations. "The population of immigrants currently residing in the host country resulting from accumulated successive waves of immigration, less losses each because of departures and deaths" (Pison, 2010). Immigration in France was punctuated one hand by the progress and evolution of French society in the economic field and that of human rights, and on the other hand by the needs of the labor economy and population precariousness of French society since the nineteenth century. France needed immigration especially for its inevitable linked to industrialization. Migrants came after the expatriation of their countries hopping for a better life.

According to INSEE in 2008 and according to the international definition of the United Nations, France hosted about 6.7 million immigrants. The migrants constitute $11 \%$ of the French population (Pison, 2010).

France has never ceased to be the destination for migrants, especially the Lebanese migrants, who settled in different economic and intellectual plans. France is the place of refuge, implementation and Transit for some Lebanese migrants.

\section{LEBANESE MIGRATION}

Authors who have studied the Lebanese migration are Safa (1960), Mouaness (1973) Baz (1978), Labaki (1993), Abdulkarim (1996), Hourani (1992). Since the mandate of the Ottoman Empire, Lebanon witnessed an increase in emigration in part of his population. The emigration from Lebanese was triggered by the economic and socio-political changes in the second half of the nineteenth century.

Between 1860 and 1914, following the crisis of 1860 and the First World War, the migration was held distant destinations: The south and North America, Australia and to a lesser extent to Egypt.

Between 1920 and 1945, after the First World War, Lebanon was under the French mandate. The Lebanese have begun to invest in the country especially with industrial development. The beginning of the migration was weaker than in the previous wave. The departures were to Latin America and Africa.

Between 1945 and 1975, after the Second World War, the two major destinations were Canada and Australia, for either a long-term or permanent migration, and the third destination Gulf countries for temporary migration.

Between 1975 and 1990, with the outbreak of civil war, a huge number of Lebanese citizens left Lebanon to improve their lot. The number of Lebanese emigrants who left them between 1975 and 2010 is estimated to be 1.2 million.

Lebanon has recognized a strong migration of brains and skills. In his article on how to restrict brain drain in Lebanon (How to curb brain drain in Lebanon), Hourani encounters the subject of brain drain, skilled emigration, the "push and pull" and the factors behind this emigration (Hourani 2007). The number of highly qualified people migrate who to the OCED countries increased from 41000 in 1990 to 67 million in 2000 (Docquier, 2000).

\section{LEBANESE MIGRATION IN FRANCE:}

The war (1975-1990) and its tragic consequences on the Lebanese economy are fundamental factors in the designation of a particular migration and career Lebanese in France. The Lebanese emigration to France was recently the beginnings of the 1970s and not to forget the old and many 
Lebanese French relations that have been woven since the intervention of the army of Napoleon III to stop the confrontation Community Mount Lebanon. Then during the French Mandate 1923-1945, Lebanon has experienced the development of infrastructure and cultural period or Lebanon knew the cultural renaissance. Lebanon has been able to benefit from all the advantages especially with the practice of the French language.

The ties that bind Lebanon to France are many and old, they often date back to the Crusades era such as Pinta rating (Pinta, 1991). Most Lebanese consider France their mother country, in the words: "Our mother France" because the majority of Lebanese had bonds with the France. Migration is always done under the influence of one or several combined factors such as political, religious, economic, social ... The Lebanese were heading to France for different reasons first because of the historical and cultural link, also for benefiting from visas, to find work and to get the french nationality. The Lebanese flow has continued heading to France especially during the civil war (Abdulkrim 1993). For Abdulkarim this immigration is an investment for immigrants to get job opportunities and the French nationality.

The Lebanese daily Annahar published an article in 2004 on the migration of Lebanese to France and believes that the number of Lebanese immigrants varies from 180000 to 200000 people.

\section{THE MIGRATION HISTORIES OF SKILLED LEBANESE WOMEN IN LEBANON.}

This section reviews the history of Lebanese migration in Lebanon. Since the 1990s, the feminization of migration flows has become a true global phenomenon. The Lebanese significantly increase the proportion among immigrants. Whereas previouse emigration was considered a male migration. Gradually, emigration has evolved and is becoming feminine too the independent migration of women is a growing phenomenon in the Lebanese societies although men still play a major important role in the migration project (Kasparian, 2010). The presence of highly qualified women is being questioned and undergoing various developments.

In the past, women were emigrating most often in the context of family reunification, and accompanying their husbands to join a member of their families. "But women emigration reasons have evolved over time. (Kasparian, 2010). The majority of migrant women today are leaving the country for so many reasons (further education, work, etc.) and not just to join their husbands or families. Women who seek work abroad make up 22.7\% of those who immigrated between 2002 and 2007. (Kasparian 2010).

Despite the fact that France and the French culture are more familiar; Lebanese in France are facing various challenges of acculturation. In her article, Maria Jio takled the identity of Lebanese youth in France. Some of these cases are: Randa T, aged 29 years old is emotionally attached to her roots, she has not yet decided whether, she is first Lebanese French, she is being discovered with time. She added that she faced racism. May K, for example stated that if a Lebanese woman staying in France and decides to return to Lebanon, she will face unequal treatment (Jio, 2011).

Jio puts the stock of the experience of integration and assimilation of some Lebanese immigrant women in France. (Jio, 2010)

In an article published in L'Orient le Jour in 2011, the proportion of Lebanese women in France now makes up $48 \%$ of the migrant Lebanese population (Mouhanna, 2011). They left to join a member of their families, to pursue their studies or work. Then they undergo a new life is to be the last one in the host country free of local traditions weight different than (sexual liberation, redefinition of their role in their family). Mouhanna reports in his article that a Lebanese interviewed stated that "I feel that since I emigrated, social barriers are more easily and more especially my privacy is respected "(Mouhanna, 2011).

What is the effect of Lebanese migration on the Lebanese women's professional social and personnal life and their independence and autonomy? 


\section{METHOD OF RESEARCH}

Conducting a study on qualified female migration to France and adaptation must take account of regions where immigrants come from, the diversity of occupational categories and socioeconomic to which they belong to. We treat a subject rich and more or less delicate or qualified migrant Lebanese woman.

In this study on highly skilled female migration to France, we will try to analyze the causes of this movement, from the reasons and the choice of France as a destination migration path, the consequences of female migration on their working lives and personal, their integration into the French labor market, then the cultural and social factors and family specifically target research on prospects remain there or return and autonomy of these women.

The study includes qualitative analysis of twenty five case studing Lebanese skilled migrant women in France,were conducted between June 2012 and March 2014, in particular, holds a university degree or equivalent (nurses, architects, teachers, doctors, engineers, lawyers, researchers ...) who were not married or go join their families when they have emigrated, and have a good command of the French language, and who were not holders of dual nationality.

It is necessary to remember that the sample selected for the survey is not representative of the number of Lebanese living in France and belonging to various socio-professional categories. We have defined the number of twenty five women in our sample. So we let the chance to interview in the choice of people when it comes to their socio-professional categories. We will use, among others, the technique called the snowball to select our sample. Our sample is characterized by the diversification of several criteria: the geographic origin of these migrants, religion, links with the country of origin, occupations and their social integration.

We will perform the biographical approach to conduct the research. This approach sees the individual as the product of all his biographical experience and posits three areas of its relationship to history ( Gaulejac, 1987):

- The individual is the scope of an individual story, rushed into a family's history which itself in turn is precipitated in a social history;

- The individual is an actor of history because it has a margin of freedom to make his destiny something that belongs to him;

- The individual produced history because it undertakes a reconstruction of the past to which it likes to create a sense of continuity and personal identity.

The methodological tool of this approach is the life story, that is to say an individual does the narration of the story of his life. The methodological approach of this study is based on the inclusion of the perspective of migrant women themselves. This approach has gained importance in geographic studies of gender (Chant, 1992; Lawson, 2000).

The study is thus based on direct communication with women through extensive interviews about their histories and migration experiences (Ellis and Bochner, 2000).

To conduct the research, we will initially select migrant Lebanese in Paris, where the concentration of the Lebanese is visible, and if we do not find candidates sufficient to Parissecondly in other cities such as Nice, Lyon, Marseille, Strasbourg, Besançon, Poitiers, Caen,... The characteristics of these selected migrant concepts are:

- Having left Lebanon alone,

- Their first university degree in Lebanon and travelling to continue their studies or work in France

- Who have left Lebanon in the last 20 years.

For a first visit to France in October 2011, we were able to make contacts with various heads of institutions such as NGOs, associations (Lebanese and French-Lebanese), and religious and political parties, to put us in direct contact with migrant Lebanese women.

We chose three ways to achieve our interviews: the first direct face to face interviews with migrants in France, a second option is to distribute our questionnaire by mail, and the third is to carry out the interviews we cannot achieve in France by Skype. Interviews were tape recorded. We have used pseudonyms for the women in order to protect their anonymity. 


\section{1-Characteristics:}

The study includes twenty fives well-qualified women, coming from different Lebanese areas : Beirut, outh, North, Mount Lebanon and Bekaa, (Beirut, Jezzine, Bint Jbeil, Chyah, Zahlé, Fatqa , Kartaba, Mazraat Yachouh Betroun, Zghorta, Jouieh, Kferzbyan, Beit El Chaar). The women are between 25 and 60 years old, some women are binational (they have Lebanese and French nationality), they come from middle- or upper middle-class families in Lebanon. Before the migration all the women were single, and after the migration we have seventeen single women, six are married (four to Lebanese men and two with French) and two divorced. Some of the women speak french well. Eighth women are mothers of young children. They are Christian and muslim. Aline was born in 1982 in Lebanon Zgharta, (she was 31 years old at the time of the interview). She has a double nationality (Lebanese and French. The French natiolnality was obtained in 2008 by an application on file at the successive stay to work in France). She is single. She is Maronite. Her father is the director of the Lebanese Official High School. Her mother is a math teacher in a private school for primary classes. She is the second child in her family. They are three boys and one girl. Her three brothers are all in France. Elie was the eldest having a Masters in Law from USJ in Beirut and then he studied Political Science in Paris at ENA. He worked at the Ministry of Health. Aimen studied economics at USJ in Beirut, he works in computer software sales business. Wael studied Economics at USJ in Beirut and continued his studies at ICP in Paris he did an internship finance at the bank.

The following section begins with a description of the women's academic qualification.

2-Academic qualifications: The women started their studies in Lebanon. After migration to France, many skilled Lebanese women were confronted to continue studying. In some cases, women come to France to study and search for a Job.

Sahar has pursued a Bachelors of year biology at Saint Joseph University in Lebanon. She continued training in France. She obtained a Bachelor and a Masters in Biology in France. On the day of the interview, she was preparing a thesis in progress in Biology at the University of Strasbourg.

Nathalie continued her studies at the Franco-Lebanese school in Tripoli (private school), she made a specialty Bac Mathematics in 2000. Her last diploma obtained in Lebanon in 2003 was a degree in Nursing at USJ Tripoli. In France, she got a Master in Economics and Health Management in 2008. Nadine went to high school in Val Pere Jacques, jal el dib (Private school). She obtained in Lebanon before going to France master degree in architecture in October 1998 in the Holy Spirit University Kaslik (USEK). She continued training in France DEA territory development at the University Paris La Villette, Paris VIII.

\section{3-Migratory process:}

None of the interviewed women initially intended to migrate. All the women expressed how difficult it was for them to decide to leave their countries; they were obviously torn between their professional local futures and their experiences abroad. The decision to migrate to France was a period of time for continuing their studies or due to the lack of jibs in Lebanon. Also the migration movements of the women reflect: only twenty two women took one direct step to France, whereas the one woman moved before to Italy for wok reasons before finally settling in France and one woman to Ukraine for family reasons and the latest women evacuated after the civil war in Lebanon in 1990. In summary, the women's stated reasons for migration, the long periods of decisionmaking and the hesitant migration movements all underscore the arriving for study and stay for work or for work.

\section{3-Migratory process:}

None of the interviewed women initially intended to migrate, and they first considered a move well after they had an adventure. All of the women expressed how difficult it was for them to decide to leave their home countries; they were obviously torn between their professional futures at home and their experiences abroad. The decision to migrate to France for a period such continuing their study 
or due the lack of jibs in Lebanon. Also the migration movements of the women reflect: only twenty two women took one direct step to France, whereas the one woman moved before to Italy for wok reasons before finally settling in France and one woman to Ukraine for family reasons and the latest women evacuated after the civil war in Lebanon in 1990. In summary, the women's stated reasons for migration, the long periods of decision-making and the hesitant migration movements all underscore the arriving for study and stay for work or for work.

Rola left Lebanon in December 1998. During migration, she was single. She left Lebanon for a job in the UNESCO in Paris and pursued her studies in Paris. The attitude of her parents towards her decision was respectful. In Lebanon, she lived, before the first departure in Haret Sakhr, (Jounieh) with her parent. She went to France in 1998. In France she lived in the same apartment until the day of the interview.

She stayed in Italy before arriving to France. She was walking in the tourism framework and as a discovery of potential destinations after graduation. Initially in France, she lived alone. And after two years, she got married and she lived with her husband and later with his family.

She has worked in Lebanon before her arrival to France in the field of architecture.

Her profession was similar in France: to that cultural assistant in UNESCO and then certified architect.

She found her first job in France due to a French agency of recruitment visiting Lebanon. She worked at UNESCO delegation of Belize full time, from 9.am to 6.pm. She put Twenty minutes on foot to get to work. She is happy in her work because it suited her on all wages levels, learning, making new contacts.

Layal left Lebanon at the end of May 2004 for work in France and mainly for studying. After high school, she made the BA in nursing in Lebanon. Her goal was to study abroad to continue her education. The Agency of private recruiters gave the opportunity to travel in France in order to work. She was paid six months in advanced. These recruiters encouraged to travel to France knowing that France was the country that first she choose. Her Family also encouraged her first two years, but she really liked the ambiance there and then salary. In France she became independent; she lived alone in an apartment

In another case, Christelle had the experience in Lebanon (she worked there). Then she came to France and found her job by personal initiative. She has been workly in France in a company of insurance since 2003.

4- Work experience in Lebanon and in France: This paragraph describes the situation of professional integration for the majority of Lebanese women studied in this paper: The main aspiration expressed by Lebanese women in the interviews carried out by this study is to work in the profession and at the level of which they were trained. As noted earlier, all these women have university degrees and some of them also have postgraduate qualifications. They have achieved a relatively high level of economic integration in the professional public and private sphere. Although this has often resulted from necessity (the salary is not always enough to support herself and or her family or the job were often lower than their level of qualifications), In this paragraph we highlighted those who had some work experience in Lebanon and come to find a job in France or on behalf of recruiter coming to Lebanon to recruit them. Women have also proved to be excellent professionals in France. The majority of women are working in their specialty.

Twelve women are coming to study in France and find a job in parallel to their education and after staying in France after finding a job on place. Eight women are coming to work and finaly 5 are recruited via agency coming to Lebanon.

Samar worked in Lebanon before arriving to France. «I gained an experience before coming to France, but I saw that my achievements do not stop here. I should improve in time ».

She found her first job in France in 2003 through her French friends. She changed five kinds of Job. Actually she is a senior executive at Oradia. She works full time. "I work a lot between nine to ten hours per day». She earns 5,000 euros net other the bonus. She drives forty five minutes by car to get to work. When we evaluate her experience Sahar said: I'm happy in my work. I like it. It's a 
varied international job. I work in a multicultural environment in France and abroad. I am in contact with people of different nationalities. Such as to the United States and England. It's very rare to have such an opportunity in Lebanon. This position gave me the opportunity to know the labor law which in France and England, that gave me the opportunity to travel either to France or abroad (is not the case in jobs found in Lebanon).

Evaluating the problems to expect a similar job in Lebanon she said:

Samar: What prevents me from having an equivalent position in my country is that Lebanon lacks the company. I work at the headquarters in Paris and at the same time responsible for the HR team. The post cannot be found in another company.

Moreover Jane is so Happy in her job: She is pleased with her work: She earns 2000 euros. She repeats "if I'm going to work in Lebanon I do not find a salary more than \$ 400". As for her professional life / in Lebanon, she does not find the same position in Lebanon and according to her graduate degree, "If you do not know anyone you cannot work in Lebanon you need a personnal means ". Simply "personal means" prevent people from having to work in Lebanon.

When evaluationg her experience she said:

Jane: "I was happy to leave Lebanon because I was not able to find a suitable work with the conditions traveling was an opportunity to do something else"

Another example is Mona (25 years old), she did not work in Lebanon before her arrival to France. In France, she got a $\mathrm{PhD}$ in Neuro Science. She found her first job through personal initiative. She works at the University of Strasbourg in France, full time 9.00.a.m-18.00 p.m. It brings twenty five minutes to go her work through the public transport.

She is happy with her work since in Lebanon she wouldn't have found.

As for her professional life / career she couldn't find a similar job in Lebanon. Nowadays, the opportunities are resign in Lebanon; whoever they do not have the same conditions.

She is working in parallel with my thesis on an international project between Switzerland, Germany and France. For her the International opportunities are found in France more than in Lebanon.

What prevents her from having an equivalent position in Lebanon an opportunities, working conditions.

"Here [In France] the participants approve their competences to reach a job and not such in Lebanon we have the piston and the religious distribution.

Another case Rania has done training in Lebanon and worked in a hospital as a nurse at North CHN four to five months after graduating.

In France, she worked in a hospital. She is responsible for all paramedical side service in the Foch Hospital. She worked as a nurse for the first job in a private clinic in Neuilly for 3 years. During the two years of Masters she worked a night job as a guard.

She is an employee and working full time. She starts in the morning from 9.00 a.m or 9.30 p.m. She stops in the evening from 18.30 p.m or 19.00 p.m, Monday to Friday. She has a status frame, is not paid for overtime. It takes 35 minutes to get to work.

She likes to change her work to evolve. She would like to be a professional nursing not for her whole life. She decided to change from nursing to Management.

She is happy in her job. She works with her manager and with a team and all is well going.

She earns about 2,500 euros in Paris per month and in parallel she makes night guards she makes a Gappe 3000 euros to 3100 euros it works in a private clinic that has nothing to do with his work.

This paragraph shows that immigrant Lebanese women in France are not passive to the forces that push them out of full professional participation. They have developed gender visibility on the French labor Market. The participants described how they have organized themselves in social networks to reach jobs or by personal initiative.

5- Experience lived in France: The above observations make it plain that migration has a definite effect on the living conditions, the integration, the autonomy and the identity of female migrants on the social, family and personnel levels. 
This paragraph addresses the different experience of women of integration in the French society, Women are well integrated in France. For them the word integration is to live fully in society, adapting well to the life in the country, adapt to her way of life, accept the country's laws, language, mentality, ethical and respect for human rights.

The word integration for highly skilled women is the fact of not feeling foreign and be part of the new community. The integration for them is the fact of life. They keep their Lebanese origins. They are attached to Lebanon. Despite them they manage to live in France. The integration, for them is opening on a new culture

Rita is incorporated in France, "I made an effort to integrate. I spoke the language. I tried to integrate social life. I respect the traditions and culture of the French people. I tried to do my duty as a citizen. "The word integration for her is feeling good in a country, know their rights and fulfill her duties.

The experience of Noura brought her to work more on her personality. she is much more comfortable because she has the French nationality which facilitate her daily life. Growing up she met people, she made relation and she opened to the world more than she did in Lebanon. The prep training taught her many things in her works and gave her knowledge.

"I discover each day the country. I have to adapt. Every day I discover things I have to adapt quickly taking in consideration vigilant social rules.

In their spare time, they make all kinds of leisure, sport, expo museum visit, active social life, drive discovery of France and Europe. They also go to watch movies, they walk in parks and they pass the majority of time with friends. Their friends in France are from different nationalities: Lebanese, French, Chinese, Japanese, Spanish... The bond of friendship that groups with their friends are coworkers, Lebanese friends, French friends or college friends.

The consequences of the migration on the personal level are summarized by their autonomy and the spirit development. Nada lived autonomy. She learned to count on herself.

The impacts of migration on family life have also been positive. Links with parents are strengthened since women contacted the parent every day to stay in daily contact with them. Despite the distance.

The impact of migration on social life for women also positive, they were able to get closer, they change into becoming independent. Their have social life developed which is not the case in Lebanon. It is much flourished and met many people. She had an expansion of social ties of social life.

Aline "I went to France knowing no one there. Yet, I did an effort to met friends and meet people".

Randa "At first, I thought that my life will be similar to that in Lebanon. With time I discovered more independent and open to the world. Then I made some new relations with other and made new friends.

"Compared to what has changed the most in the lives of women in France to that in Lebanon: are opening to the new horizons, to be more independent, more responsible, more professional ... They learned be truly citizens and they learned their rights and duties.

How Sahar's life in France: She started as a student and then turned to the employee. Her way has changed completely. She does not come back to Lebanon. She is financially independent in France. She changed her style to become like the French people.

She added: "If I return to Lebanon I would like directly regain the stress that I was living in".

When we asked the participants: Do you advice Lebanese women to follow the same path that your followed? The majority of the participants, advice Lebanese women to follow the path they had chosen because their living conditions differ and it improves their social and personal life. Their life will change. They will have an independent life. 
Rita replies: "it depends on each person's decision, If she wants to immigrate, she will seek a professional and personnel development. If she doesn't, it is her choice".

\section{6- Migration and future perspectives}

For the future, some women would like to stay in France, others would like to return to Lebanon, and others would like to change their destinations.

In this study twenty women decided to stay in France for many reasons work, rights, integration... and three women only decided to come back to Lebanon after the retirement and two decided to change definitely their destination.

Mary's post of view is that she gets the same job opportunity to Lebanon, she will prefer returning. She's just staying in France for her Job. What she appreciates most about her life in France is the Freedom. If she returns to Lebanon, she feels that her relationships with her family and society will change. Her life in Lebanon won't be at easy since her relation with the family and society will be different this is because of the lack of expressing one self and the life stress.

\section{7- Migration and link with the original country:}

The travel to Lebanon and the Internet Have become available to a variety of women living in France. This permits then to be in contact with friends and family members in Lebanon. This happens due to the social media and applications such as Skype, viber, international call by phone, and what's up.

The twenty five participans come to Lebanon two times per year for Christmas and for the summer holidays.

Nagham kept in touch with people from Lebanon such childhood friends. She communicated with them via email and internet, phone, facebook, email and the distance wasn't a problem that put her a part from her friends.

\section{CONCLUSION}

This study of skilled Lebanese women in France provides insight into several issues of female migration. These issues include the reasons, characteristics and effects of migration, the integration, and the autonomy.

It is argued that women become more independent, earn their own money and have a stronger position within the family.

After conveying the results of this study, these results opened a new horizon for a new perspective. This perspective is based on the comparaison of the experience of returnees highly skilled migration lived in France and in Lebanon.

\section{References}

[1] A. ABDULKARIM, Les Libanais en France: évolution et originalité, Revue européene de migrations internationales, 9 (1993), 1,113-129.

[2] H. ABU SAAD-HUJJER, Developing the nursing workforce: Challenges and opportunities in Lebanon, White paper of Fulbright Academy workshop in Doha, March 23-25 2007, [www.FulbrightAcademy.org].

[3] A. AL ARISS, (2009), Personal, professional and societal influences shaping career and study of Lebanese self initiated expatriates "whole lives" work-in -progress-CM 6 Conference 2009.

[4] C. CATARINO, Christine,M.MOROKVASIC,Femmes, genre, migrations et mobilités, Revue Européennes des Migrations Internationales, vol 21, (2005), $\mathrm{n}^{\circ} 1$.

[5] S.CHANT ed., Gender and Migration in Developing Countries. London, New York: Belhaven Press.(1992). 
[6] C. ELLIS, A. BOCHNER, « Autoethnography, Personal Narrative, Reflexivity:Researcher as Subject », in Denzin, N. K. and Lincoln, Y. S., eds., Handbook of Qualitative Research, London : Sage, (2000), pp.733-768.

[7] V.GAULEJAC de, La névrose de classe. Paris: Hommes et Groupes Éditeurs, (1987).

[8] F. EL-JARALDI, D.JAMAL, M. JAAFAR, Z. RAHAL, Analysis of Health Professionals Migration: A Two-Country Case Study for the United Arab Emirates and Lebanon. Draft discussion October 2008. Department of Health Management \& Policy, Faculty of Health Sciences. Amercican University of Beirut. 156p.

[9] F. EL-JARALDI, N. DUMIT, D. JAMAL, G.MOURO, Migration out of Lebanese nurses: International Journal of Nursing studies n $\mathrm{n}^{\circ} 45$, p. 1490-1500. (2007).

[10] S.KARAM, Communication au colloque Gender and migration in Lebanon, Hotel Merdien Commodore, Beyrouth, July reported by Basma Abdul Khalek, (2008),

[11] C. KASPARIAN, Migration et féminisation au Liban, CARIM-AS (notes d'analyse et de synthèse) 2010/70, (2010).

[12] F.KIWAN, H.ITANI, La migration au Liban sous l'angle du genre, CARIM-AS (notes d'analyse et de synthèse) 2011/21,(2011),.

[13] V.LAWSON, " Arguments within Geographies of Movement: The Theoretical Potential of Migrant's Stories », in Progress in Human Geography, n²2, (1), pp.39-53,(2000).

[14] M. JIO, France c'est la vie: Immigrant Lebanese woman in France, Women Feature Service,(2010), http://periodicals.faqs.org/201012/2235443001.html

[15]P. MOUHANNA, Des Libanaises de Paris témoignent quand émigration rime avec émancipation l'Orient le jour, 2011, Source, [http://lorientlejour.com/numero/4039/article/685283/Des_Libanaises_de_Paris_temoignent+\%3A_ quand_emigration_rime_avec_emancipation.html]

[16] OIM, Rapport sur l'état de la migration dans le monde : Gestion de la mobilité de la main d'œuvre dans une économie mondiale en mutation,2008.

[17] P. Pinta, Phéniciens et paysans : L’émigration libanaise en France, Hommes et Migrations, n 1149, pp 28-34, (1991),

[18]G. PISON, Le nombre de la part des immigrés dans la population : comparaison internationales Population et Sociétés numéro 472, Novembre 2010.

[19] H. ZLOTNIK, The global dimensions of female migration, Migration Information Source, (2003) [http://www.migrationinformation.org/Feature/display.cfm ? ID = 109]. 